Int.J. Hum. Soc. Dev. Res.

ISSN (P):2521-1439; ISSN (E):2523-4331

Volume 3, № 1, 2019. 45-57

DOI: $10.30546 / 2523-4331.2019 .3 .1 .45$

\title{
THE SOCIO-CULTURAL AND RELIGIOUS LEGACY OF THE LUSOPHONES ON NIGERIA: A DISCOURSE
}

\author{
Adewunmi J. FALODE \\ Lagos State University, Lagos, Nigeria
}

(C) The Author(s) 2019

\begin{abstract}
The paper is an attempt to show Nigeria's relationship with the Lusophones countries. TheLusophones are countries that became tied to Portugal from the $14^{\text {th }}$ as a result of $v$ oyages of discovery and colonialexploration. Nigeria, though a country with an Anglophone heritage, was one of the earliest countries touched by Portuguese colonial exploration in the $14^{\text {th }}$ century. The contact with Portugal left important cultural and religious impact on Nigeria. This study shows the relationship between Nigeria and Portugal on the one hand, and between Nigeria and the other countries in the Lusosphere. The research emphasizes the pre-colonial, colonial and post-colonial interactions among the different actors. This is a qualitative research that highlights the neglected aspect of the crucial legacies Portugal and its satellites had on Nigeria.

¿2019.All rights reserved
\end{abstract}

\section{ARTICLE HISTORY}

Received: 30/12/2018

Accepted: 28/03/2019

Published online: 01/04/2019

\section{KEYWORDS}

Lusosphere, Lusophone, Nigeria, Portugal, Colonial Rule, History, Cultural 


\section{Introduction}

The relationship between Nigeria and the Lusophones is multifaceted. The Lusophones are countries in Africa, Europe, Asia and South America that adopted Portuguese as a national language. These countries are Portugal, Brazil, Angola, Guinea-Bissau, Timor-Leste, Mozambique, Sao Tome and Principe, Macau and Cape Verde (Cardoso 1997). As stated earlier, Nigeria's relationship with the Lusophones is variegated. Rather than analyse Nigeria's relationship with the Lusophones as a bloc, the study will analyse the country's interactions with individual member states within the Lusosphere (a community of people who are culturally and linguistically linked to Portugal). At independence in 1960, Nigeria became a member of international organizations such as the UNO and also signed bilateral and multilateral agreements with independent states within the international political system. Apart from establishing friendly relations with African states, the country also established crucial links with various European states. Of critical importance to the survival of the new state was the special relationship Nigeria established with its former colonial master, Britain, and because of its overweening influence over some of the country's neighbours, then France. Nigeria's relationship with the Lusophones lacked such a colonial antecedent. Interactions between Nigeria and some of the members of the Lusophones predates colonial rule. These interactions have been largely ignored and have created the erroneous impression that the British single-handedly influenced religious and educational development in the Nigeria. Due to the fact that Nigeria was colonized by Britain, researchers have always focused on the historical relationship between her and the Anglophone states. This work is important because it tries to refocus that narrative and show that Nigeria had been influenced by the Lusophones in the pre- and post-colonial period.

\section{Nigeria's Colonial Past: A Brief Historical Survey to 1960}

The borders of modern day Nigeria were established in 1914 by British colonizers, but the histories of the peoples that make up the Nigerian polity go back many centuries (Falola \& Heaton 2008). The country is bordered to the south by the Bights of Benin and Biafra, which are on the Gulf of Guinea in the Atlantic ocean. On the west Nigeria is bordered by Benin, on the north by Niger and on the east by Cameroun. In its extreme northeastern corner, Lake Chad separates Nigeria from the country of Chad. The main artery of commerce and communication in the region historically has been river Niger (Falola \& Heaton 2008). The Niger enters the country in Kebbi state in the northeast and pours into the Gulf of Guinea through its many braches in the Niger Delta in Cross Rivers and Delta States. The Niger joins with its main tributary, the Benue, which flows from the northeast at Lokoja, in the central state 
of Kogi (Nwachukwu \& Uzoigwe 2004).Nigeria's large population is very diverse, consisting of over 250 different ethno-linguistic groups (Muhammad 2007). Three main ethnic groups make up the majority of the population. The Hausa, located in the northern savannah, account for roughly 21 percent of the population, while the Yoruba, located in the southern part of the country, make up 20 percent, and the Igbo located in the east 17 percent (Central Intelligence Agency 2007). Other ethnic groups with relatively large populations include the pastoral Fulani of the savannah, the Ijaw of the Niger Delta region, the Kanuri of the Lake Chad region, the Ibibio in and around Calabar in the southeast, and the Nupe and Tiv of the middle Belt region (Falola \& Heaton 2008). British colonial rule in the nineteenth century brought these diverse ethnic groups together.

The nineteenth century brought great changes to the states in the Nigerian region. Although, social formations within the various geographical regions remained diverse, several relatively large centralized states came to dominate geopolitical and economic dynamics during this time. In the northern savanna zones, the Islamic Jihad of Uthman dan Fodio led to the establishment of the Sokoto Caliphate. The Caliphate brought under one government all the Hausa states, as well as some former provinces of Borno and lands in the south and southeast respectively (Balogun 1980). Uthman Fodio and his successors reconfigured the political and cultural landscape of the northern savanna towards a primary identification with Islam by 1903. By the time the British colonial forces sacked Sokoto in 1903, the caliphate that Uthman Fodio established had succeeded in wielding such Hausa city-states as Gobir, Zamfari, Kebbi, Kano, Katsina and Zazzau into a monolithic theocracy (Balogun 1980). In the southern regions, the nineteenth century was a period of great socio-political and economic transformations. By this time, Oyo, a najor Yoruba metropolis, was an acknowledged military power in the region. Oyo was a major supplier of slaves to the coastal ports of Porto Novo and Lagos (Uzoigwe 2004). However, internal conflicts in the early nineteenth century resulted in Oyo's collapse by the 1830s. Oyo being a unifying factor in the region and a force for stability, her collapse led to a century of wars in the region. Yoruba states previously held in check by the might of Oyo fought to fill the power vacuum created y Oyo's decline. To the east of the Yoruba are the Edo-speaking peoples. The Edos are historically famous because of the kingdom of Bini and their bronze work. The Ijaw constitute the majority group in the Eastern Delta in the present Bayelsa state.

These were followed by the Ibibio who constitute the largest group in the basin of the Cross River. The Igbo are concentrated in present-day Imo, Abia, Anambra, Enugu, Rivers (the southern Igbo) and Delta states(the western Igbo) (Ejiofor 1982). The largest Igbo towns include Onitsha, Enugu, Owerri, Aba, Umuahia, Abakaliki, Afikpo and Orlu. 
The Grassland zone is divided into the Middle Belt and Far North. The Middle Belt has the largest concentration of Nigeria's ethnic groups. Uzoigwe has estimated the number to be around one hundred and eighty (Uzoigwe 2004). The two prominent groups are the Nupe of the Middle Niger River valley in the west and the Tiv of the Benue valley in the east. The Belt crosses Nigeria from west to east and from south to north. Today, it includes the following areas: Kwara, Kogi, Niger, Plateau, Adamawa and Taraba states. The Hausa-speaking peoples are found throughout the grassland zone of West Africa. In Nigeria, they are dominant in Kebbi, Sokoto, Katsina, Kano and Jigawa states. The Hausa founded a number of city-states that were independent of one another until the Fulani conquerors from the north subjugated them early in the $19^{\text {th }}$ century. Each of the ethnic groups evolved specific institutions that were designed to guarantee their sovereignty and independence from external aggression; and at the same time preserve their unique socio-cultural meme. For example, the highest decision making authority in Oyo Empire was the Alaafin. The Yoruba evolved the monarchical system of government to regulate their day-to-day existence. On the other hand, the Hausas evolved what one can call a theocracy. This was particularly evident during the period of the Sokoto caliphate in the $19^{\text {th }}$ century. Nigeria's ethno-cultural heterogeneity and sovereignty was to be a recurring theme in the nation-building process of the country in the post-independent era. There are two types of political societies in Nigeria before the advent of colonialism in the $19^{\text {th }}$ century: centralized and decentralized states. Centralized states are those ones with a political hierarchy and that has political authority rooted in an institution or an individual. This type of state was obtainable in Western and Northern parts of Nigeria among the Yoruba and the Hausa people. Decentralized states are those ones without any easily identifiable central political authority or institutions to govern the affairs of the people. Political hierarchies in such societies rarely reached higher than the village or village-group level. Cultural and agegrade groups tend to predominate in such societies. A good example was the Igbo in the southeastern part of Nigeria (Falola \& Eaton 2008).

\section{[i] British Conquest of Nigeria, 1861}

British conquest of Nigeria by the close of the $19^{\text {th }}$ century was the culmination of a long process that started with the slave trade and its suppression. This culminated in the occupation of Lagos in 1851 and by 1861, Lagos was formally declared a British colony (Ikime 1977). The expansion of the Lagos colony initiated the conquest of Nigeria. Interference in local politics eventually led to direct British control of the coastal states between 1861 and 1885 (Falola \& Eaton). From Lagos, the British made their way inland, slowly bringing Yoruba land under colonial rule. In 1886, the British used her intervention in the Ekitiparapo war, which was fought between Ibadan and the alliance of Ekiti, Ijesa, Egba, Ijebu and Ife forces, to subjugate the major Yoruba kingdoms. Unknown to the Yoruba kingdoms then, theirs was to form the 
crucible of the nascent southern protectorate. A key provision of the treaty the British used in ending the war made it compulsory for all the signatory combatants to direct future disputes with each other to the British governor in Lagos for resolution. In 1892, the British subjugated and occupied Ijebuland. And by 1894, the newly reconstituted new Oyo that initially offered stiff resistance to British penetration of the Yoruba hinterland, was bombarded and forcefully brought under British colonial rule. In the port cities of the Bight of Biafra, as in Yorubaland, Britain used the promotion of antislavery and British trading interests as key aspect of the rhetoric that led to colonization. Between 1849 and 1856, Britain succeeded in subjugating such port cities as Creek Town, Duke Town and Calabar (Ikime 1977). Between 1853 and 1897, the British succeeded in subjugating and colonizing states in the Delta such as Opobo, Bonny and Elam Kalabari. By 1897, the kingdom of Benin was forcibly brought into the protectorate, expanding its western boundary to reach the eastern limits of the Lagos protectorate (Ryder 1969). Sir George Goldie's Chartered Royal Niger Company (RNC) was instrumental in gaining control of the Niger and Benue for the British. In 1886, the British gave the National African Company, later renamed the Royal Niger Company, the power to control the political administration and trade policies in the Rivers Benue and Niger regions (Flint 1960). The charter established a British sphere of influence over the Niger and Benue. In 1899, the British government revoked the charter it gave to the RNC and took direct control of the administration of the Niger and Benue. On January 1, 1900, the RNC ceased to be the governing authority of the Niger and Benue (Ikime 1977). RNC's southern territories in the palm oil zone near the Niger Delta were amalgamated into the Niger coast protectorate, forming the new protectorate of southern Nigeria. The company's northern territories became the protectorate of northern Nigeria. Frederick Lugard was then named the first high commissioner of the northern protectorate. By 1900, Britain turned her military might towards the emirates of the Sokoto caliphate. In a series of military offensives led by Fredrick Lugard, Britain finally brought down the caliphate in July 1903. The caliphate's territories were incorporated into the protectorate of Northern Nigeria. By 1904, Borno that had fiercely resisted British occupation was eventually conquered by British forces and brought into the protectorates. Thus, bringing under British imperial control the lands that were later to make up the amalgamated Nigerian protectorates in 1914.

\section{[ii] The Indirect Rule System}

Frederick Lugard became the high commissioner of the protectorate of Northern Nigeria in 1910 (Metz 1991). During his six year tenure as high commissioner, Lugard concerned himself with transforming the commercial sphere of influence inherited from the RNC into a viable territorial unit under effective British control. In achieving this aim, Lugard introduced the policy of indirect rule. Indirect rule called for the governing of the protectorate through indigenous rulers. In the case of the northern protectorate, it meant the use of emirs, who had accepted British 
suzerainty, as the recognized authorities in their respective emirates. Under the system, the emirs retained their caliphate titles, but were now responsible to British district officers who had final authority. Under indirect rule, caliphate officials were transformed into salaried district heads and became agents of the British authorities responsible for peacekeeping and tax collection. Taxes collected by local officials were used to support services of the colonial regime because the protectorate lacked fungible public resources (Afigbo 1972). In the north, Lugard and his successors limited the activities of missionaries in other to maintain Muslim domination. Consequently, educational and medical services, which were provided in the south by missionaries, lagged considerably in the north. Efforts to apply indirect rule in the south was partly successful. Lugard's policy was successful in the north because there were indigenous authorities he used to implement the policy. The task proved relatively effective in Yorubaland because traditional kingdoms and boundaries were retained and because they were a centralized state. Particularly, the monarchical system in Yorubaland ensured a successful implementation of the policy. In the southeast, especially among the Igbos, the policy was unworkable. This was because there were no acceptable indigenous authorities that commanded the respects and loyalties of a vast majority of the inhabitants of the region. Government among the Igbo, Ibibo, Urhobo and other hinterland societies was based on village or village-group councils along the lines of representative democracy (Isichei 1976). As a result of this, the tasks of government initially rested in the hands of colonial officials. To make their tasks easier, the British authorities, starting with Claude Macdonald in 1892, established native courts. The authority of the native courts were derived entirely from the British "certificate of recognition," or warrant, that a court member received on taking office. Since the British colonial authority could not lay its hands on indigenous authorities with wide representation in the southeast, she resorted either to consultation with the local people (Afigbo 1972).

\section{[iii]The Amalgamation of 1914}

The protectorates of Northern and Southern Nigeria and the Colony of Lagos were amalgamated under a single British administration in 1914 (Elaigwu \& Uzoigwe 2001). The amalgamation of 1914 meant the bringing together of the three distinct regional administrations into which Nigeria was subdivided. Each was put under a lieutenant governor and provided independent government services (Metz 1991). In the Northern Region, the colonial government ensured that the Islamic system and the social-cultural affinity of the people was never disrupted. The colonial authorities maintained the status-quo, especially on religious matters. Foreign influence was severely restricted from interfering with the indigenous socio-political system met on the ground. In the south and the east by contrast, the British tried as much as possible to alter the status-quo. External influences, especially Christian missionaries, were allowed relative freedom to interfere in indigenous socio-political and religious activities. This 
meant in essence that the south became much more exposed to western education and socio-political system; while in the north, the British policy ensured limited contact of the region with western influences. It is pertinent to point out here that the major reason for the amalgamation of 1914 was economic (Crowder 1973). In spite of Lugard and his successors' efforts, the economy and finances of northern Nigeria had floundered under indirect rule. British colonial policy then was for each colony to be self-sufficient and self-financing. To make the northern protectorate economically viable during the early stage of colonial rule, the British government had to rely on annual subsidies from southern Nigeria and an imperial grant from the home government (Crowder 1973). Thus, in order to surmount this crippling economic challenge being experienced in the northern part of the protectorate, the British government had to centralize the protectorates under a single administration. Amalgamation allowed the colonial authorities to streamline existing expenses and allowed the central administration to divert resources as it saw fit.

As can be seen from the brief survey, anglophone influence in Nigeria has deep historical roots. Britain not only dominated Nigeria political landscape but also its social and religious aspect. This has created the impression that Nigeria had no relationship with other foreign states and cultures in the pre-, colonial and post-colonial period. It is the contention of this paper that Nigeria had important relationship with the Lusophones that cuts across political, social, religious and historical spheres. For the sake of clarity and intelligibility the relationship between Nigeria and the Lusophones is going to be examined under the following sub-headings: political, religious, historical and cultural context.

\section{Historical Context}

Portugal was the first among the Lusophone states to come into contact with Nigeria. Long before the advent of British colonial rule in the $18^{\text {th }}$ century, Nigeria has already established trading links with Portugal. This started with the Portuguese exploration of West Africa in the $14^{\text {th }}$ century. Propelled by commercial, religious and political motives, the Portuguese made successful trips to the coast West Africa in search of gold, spices and slaves (Onwubiko 1966). Their first port of call in Nigeria was the Niger Delta where they made contact with the locals in 1469 (Ryder 1969). The procurement of slave for her trading activities in the Gold Coast was what brought the Portuguese to the Niger Delta. Since trading activities in the Delta were controlled by the Benin king, the Portuguese then extended their incursions into Benin Empire and its constituents. Apart from the slaves, the Portuguese traded firearms, cloth, copper and bracelets for pepper. But the main article of trade was the slave. In 1486, the Portuguese established a trading post at Gwatto, the port of Benin, and they conducted their trading activities in the Niger Delta from the port (Ryder 1969). In 1472, the Portuguese explored the western part of Nigeria and that was when they had a brief contact with 
Lagos. Interestingly, Portugal's passing interest in Lagos was to leave an indelible mark on the state. This is because the name of the state, 'Lagos,' is a corruption of the Portuguese word lago de curamo which means lagoon or lakes. It was coined by the Portuguese explorer Rui de Sequera.

An important legacy of the Portuguese influence on Nigeria is the creation of a 'second' unifying lingua franca for independent Nigeria. The first lingua franca is the English language that was given to Nigeria by the British. The second one created by Portugal for her trading activities in Nigeria was 'pidgin' English (Oshorenoya 2009). This is the hybridization of Portuguese and the different local dialects. From this rich tapestry has emerged such pidgin words as 'dash' (Portuguese for das) (English for give), 'pikin' (Portuguese pequeno) (English child), 'kpalava' (Portuguese palabras) (English trouble) and 'sabi' (Portuguese for sabeir) (English to know).

\section{Cultural Context}

Brazil is another important member of the Lusosphere. It has the largest landmass in Latin America. Historically, Brazil was the recipient of the largest numbers of West African slaves in the $16^{\text {th }}$ century (Rawley 1981). Most of these slaves were destined for Bahia in Brazil. Bahia had some of the largest sugar cane plantation centres in Brazil. Since the native Indians could not withstand the rigour of working on such plantations, West Africans were imported by the Portuguese to Brazil to take their place (Rawley 1981). This explains how slaves from Nigeria, especially from Lagos and its Yoruba environs found themselves in Brazil. It has been estimated that by 1600 the Africa population in Brazil was about fifteen thousand and most worked in over one hundred and thirty sugar cane plantations. Although, it has historical ties with Nigeria due to the Transatlantic slave trade, Brazil shares cultural affinity with Nigeria more than any other Lusophone state. The relationship between Nigeria and Brazil spans two clearly delineated periods. The first period was during the slave trade era when slaves taken from Lagos and its Yoruba environs found themselves in Bahia, Brazil. The second period was when manumitted slaves left Brazil for their ancestral homes in Nigeria.

The Yoruba slaves that were taken to Bahia never abandoned their cultural roots neither did they forget their traditional religions. They introduced to Brazil the ancestral worship called orisha. The Bahians readily embraced this traditional worship and it led to the syncretism of that traditional religion with the Catholicism which was the official religion in Brazil. Nigerians and Bahians blended and practised both religions. Examples of Nigeria's influence on religion in Brazil abound. For instance, Bahians believe in the worship and reverence of orisha (Alonge 1994). This is the same traditional orishas worshipped among the Yorubas in Nigeria. Yorubas in Brazil also established traditional confraternities. 
In the second period, manumitted slaves returned to Nigeria, especially to Lagos, between 1825 and 1838 (Alonge 1994) and introduced Brazilian architecture into the Lagos housing sector. This was possible because many of those who returned in the 1820 s were master masons and carpenters. Most of the returnees settled in popo aguda (Brazilian quarters) in downtown Lagos (Losi 1914). Using their experience, they altered downtown Lagos with their architectural masterpieces. Examples of these structures, with their gothic façade, can still be seen today in areas such as Ebute Metta, Bamgbose, Igbosere and Anikantamo all in Lagos.

\section{Political Context}

Angola and Mozambique are African members of the Lusosphere. Nigeria played crucial roles in setting the two countries on a democratic footing at independence in the 1970s. Nigeria was able to do this because she was invited to become a member of the Frontline States group in the 1970s (Ibeanu 2010). The Frontline States was formed in 1970 and it consisted of independent southern African countries bordering apartheid South Africa, Mozambique, Angola, Zimbabwe, Zambia, Botswana and Lesotho. The Group was meant to create a concerted and targeted response against apartheid South Africa and to provide support for the liberation struggle in South Africa. In the case of Angola, the country became independent in 1975 after a bitter and prolonged war with Portugal(Abott and Volstad 2005). At independence, three factions then emerged in the country. These are the Union for the Total Independence of Angola (UNITA), National Front for the Liberation of Angola (FNLA) and Popular Movement for the Liberation of Angola (MPLA). In 1975 when Nigeria discovered that both the UNITA and FNLA were being openly supported by the USA and apartheid South Africa, she threw her economic, political and diplomatic might behind the MPLA. For example, Nigeria nationalized the British Petroleum and its assets in 1979. This was done to punish Britain for supporting apartheid South Africa and to put pressure on her to cut her ties with the country (Aluko 1990).

Furthermore, Nigeria gave the MPLA 20million dollars as a cash grant and 80million dollars in military supplies and economic aid to help it in its drive to turn Angola into a stable, democratic and viable polity (Cann 2005). At the end of the long and bitter political struggle in that country, the MPLA eventually emerged to lead independent Angola in the 1990s. This was no doubt possible because of the important role Nigeria played in that country's drive to create a stable, democratic and viable polity. Just like Angola, Mozambique was a former colony of Portugal. The country fought a bitter and devastating war with Portugal from 1964 to 1975 when it achieved its independence. Frente de Libertacao Mocambique (FRELIMO) was the main revolutionary group that fought the Portuguese for Mozambique independence. At independence, FRELIMO took over the administration of the country. It faced a 
daunting task on the economic and political fronts. Nigeria, just as she did in Angola, played a significant role in putting the country on a sound political and economic footing. For example, apart from training top military officers from the country, which contributed to capacity building, Nigeria gave economic aids and grants to the country. Nigeria also sent military equipment to Mozambique to help the country check the subversive activities of the South African-backed Mozambican National Resistance guerrillas.

\section{Religious Link}

Portugal was the first European country to make contact with Nigeria in the $14^{\text {th }}$ century. Being a Christian state, Portugal tried to make Nigeria adopt its own brand of Christianity. This was Catholicism. The basis for Portuguese exploration of Nigeria was primarily economic. Portugal was interested in using Nigerian slaves to carry gold to the coast from the West African interior. In the process, the Portuguese realised that it will be economically viable for them if they can convert some of the locals, especially the kings and people who mattered to their trade to Christianity. This will make it possible for them to procure more slaves with ease and at the same time give them favourable trade agreements with the locals. More importantly, the adoption of the religion by the locals will create a 'standardize' language with which the Portuguese can communicate with the Nigerians. This was the reason behind the introduction of Christianity to Benin kingdom in the $15^{\text {th }}$ century. Oba Esigie (1504-1550) of Benin encouraged missionary activities in his kingdom (Adamolekun 2012). He encouraged some of his subjects to be converted and baptized and this helped the spread of the new religion. From Benin, the Portuguese missionaries moved into the Nigerian interior. By mid-sixteenth century, the new religion has reached both Warri and Itsekiri kingdoms. As a matter of fact, Augustinian monks established a Christian settlement in Warri called 'Santo Augustino' (Makozi and Ojo 1982). Using this region as a launching pad, the Portuguese carried their proselytizing into the interior of Southern Nigeria and helped spread Roman Catholicism. This in essence meant that before the advent of British colonialism in the country in the 18thcentury, Portugal had already introduced Christianity and formal education into Nigeria. It could be argued that the Christian religion was not introduced because of the desire of Portugal to spread the religion but to aid in the economic penetration of the interior of Nigeria. Nevertheless, the proselytization activity of the Portuguese missionaries played crucial roles in exposing Nigerians early to the benefit of western education. 


\section{Conclusion}

As could be seen from the analysis so far, Nigeria relationship with the Lusophones straddles both the pre-colonial and post-colonial periods. This relationship took many forms. It has been shown that the one with Portugal was both historical and religious; that of Brazil was cultural and that of Angola and Mozambique was political. Nigeria's pre-colonial interaction with Portugal is particularly poignant. Portugal left distinctive cultural influence on Nigeria in the areas of religion and education. Long before the British introduced formal education and their Anglicized version of Christianity, Portugal had already a rudimentary form of the two in the country through the activities of its explorers and missionaries.

What has become obvious is that despite the fact that Nigeria has not been involved with the group as a bloc, it has had a fruitful relationship with individual members of the Lusophones. While the interactions with some of the countries in the bloc have impacted positively on Nigeria, the country has also contributed meaningfully to the development of African members in the Lusosphere.

\section{Disclosure statement}

No potential conflict of interest was reported by the author.

\section{Contact Information}

E-mail: adewunmi.falode@lasu.edu.ng 


\section{References and notes:}

Abbott, Peter and Volstad, Ronald (2005), Modern African Wars (2): Angola and Mozambique 1961-74, New York, NY: Osprey Publishing.

Adamolekun, Taiye, (1982), "Main Trends in the Church Growth in Nigeria," European Scientific Journal, Vol. $8, \quad$ No. 23 , https://eujournal.org/index.php/esi/article/view/450, [Accessed 21.10.2018]

Afigbo, A.E. (1972), The Warant Chiefs: Indirect Rule in Southeastern Nigeria, 1897-1929, London: Longman.

Alonge, Marjorie Moji (1994), "Architecture in Lagos State: A Case Study for Conservation," $\mathrm{PhD}$ dissertation (unpublished), Department of Architecture, University of Newcastle upon Tyne, pp. 58, 65, http://hdl.handle.net/10443/883, [Accessed 15.06.18]

Aluko, Olajide (1990), "The Nationalization of the Assets of British Petroleum," (in: Gabriel Olusanya and RAfiu Akindele-Eds., The structure and processes of foreign policy making and implementation in Nigeria, 1960-1990,), Lagos: Nigerian Institute of International Affairs, pp. 375-397

Balogun, S.A. (1980), "History of Islam up to 1800", (in: Obaro Ikime-Ed., Groundwork of Nigerian History,), Ibadan: Heinemann, pp. 210-220.

Cann, Ohn (2005), Counterinsurgency in Africa: The Portugeuse Way of War, 1961-1974 Hailer Publishing

Cardoso, Carlos (1997), "Lusophone Societies and Social Facts-Problems and Challenges for the $21^{\text {st }}$ Century," Proceedings of the ISA Regional Conference for the Lusophone World, Lisboa, Portugal, November, archive-org.com/page/4390898/2014-0812/http://www.isa-sociology.org/colmemb/nationalassociations/en/meetings/reports/Lusophoneworld.html, [Accessed 17.02.2018]

Central Intelligence Agency (CIA), "World Fact Book: Nigeria," updated May 15, 2007,

www.cia.gov/library/publications/the-world-fact-book/geos/ni.vitml, [Accessed 26.02.2018].

Crowder, Michael (1973), The Story of Nigeria, $3^{\text {rd }}$ ed., London: Faber and Faber.

Ejiofor, Lambert U. (1982), Igbo Kingdoms: Power and Control, Onitsha: African Publishers.

Elaigwu, Isawa J. \& Uzoigwe, G.N. (2001), Eds., Foundations of Nigerian Federalism: 19001960, $2^{\text {nd }}$ ed., Jos: Institute of Governance and Social Research.

Esizimetor, David Oshorenoya (2009), "Historical Development of Naija," Proceedings of the Conference on Nigerian Pidgin, University of Ibadan, Nigeria, (8-9 July), p. 9.

Falola, Toyin and Heaton, Matthew (2008), A History of Nigeria, Cambridge, New York: Cambridge University Press, pp. 1, 6, 93

Flint, John E. (1960), Sir George Goldie and the Making of Modern Nigeria, London: Oxford University Press.

Ibeanu, Okechukwu (2010), "Nigeria's Role in the Formation of OAU/AU and Membership of the Frontline States," (in: Farris Jacqueline-Ed., Nigeria at Fifty: Contributions to Peace, Democracy and Development,), Abuja, Nigeria: Shehu Musa Yar'Adua Foundation, pp. 22-23

Isichei, Elizabeth (1976), A History of the Igbo People, London: Macmillan, pp. 140-160.

Ikime, Obaro (1977), The Fall of Nigeria: The British Conquest, London: Heinemann, pp. 178-184 Losi, John. (1914), History of Lagos, Lagos: Tika Tore printing Works.

Makozi, Alexius Obabu and Ojo Afolabi (1982), editor. The History of the Catholic Church in Nigeria, Lagos: Macmillan Nigeria, p. 7

Metz, Helen Chapin (1991), ed., Nigeria: A Country Study, Federal Research Division, Library of Congress, June, www.fieldsupport.dliflc.edu/products/cip/nigeria/nigeria.pdf [Accessed 05.06.2018), pp. 31-34. 
Muhammed, Abdulrasheed (2007), "Federalism and Political Stability in Nigeria: Current Peril and Future Hopes," Journal of sustainable Development in Africa, Vol. 9, No. 4, p. 187.

Nwachukwu, Levi Akalazu and Uzoigwe, G.N. (2004), eds. Troubled Journey: Nigeria Since the Civil War, New York, Oxford: University of Press of America, Inc., p. 2.

Onwubiko, Charles (1966), School Certificate History of West Africa, Book One, Nigeria: Africana Educational Publishers \& FEP International Private Limited, p. 132.

Rawley, James (1981), The Trans-Atlantic Slave Trade, New York: Norton, pp. 29, 113.

Ryder, Alan Frederick (1969), Benin and the Europeans, 1485-1877, London: Longman.

Uzoigwe, G.N. (2004), "Nigeria to 1960: An Overview," (in: Levi A. Nwachukwu \& G.N. Uzoigwe-Eds., Troubled Journey: Nigeria Since the Civil War,), New York: University Press of America, Inc., 2004), p. 7 